Journal of Telenursing (JOTING)

Volume 1, Nomor 2, Desember 2019

e-ISSN: 2684-8988

p-ISSN: 2684-8996

DOI: https://doi.org/10.31539/joting.v1i2.895

\title{
PENGARUH KEPEMIMPINAN TRANSAKSIONAL KEPALA RUANGAN TERHADAP PELAKSANAAN ASUHAN KEPERAWATAN PERAWAT PELAKSANA
}

\author{
Mohammad Nisyar Azis ${ }^{1}$, Tri Kurniati ${ }^{2}$, Giri Widakdo ${ }^{3}$ \\ Universitas Muhammadiyah Jakarta ${ }^{1,2,3}$ \\ mohammadnisyar91@gmail.com ${ }^{1}$
}

\begin{abstract}
ABSTRAK
Tujuan penelitian ini untuk mengetahui pengaruh kepemimpinan transaksional kepala ruangan terhadap pelaksanaan asuhan keperawatan perawat pelaksana. Desain penelitian ini quasy eksperiment dengan pre dan post test design with control grup. Hasil analisis data kepemimpinan transaksional berpengaruh signifikan terhadap pelaksanaan asuhan keperawatan pada kelompok intervensi dengan nilai p-value 0,000 $<0,05$. Sedangkan pada kelompok kontrol didapatkan perbedaan nilai pre dan post pengukuran minggu ke VI Pelaksanaan Asuhan Keperawatan dengan nilai p-value $0.000<0,05$. Simpulan, pada kelompok intervensi didapatkan bahwa pengukuran pelaksanaan asuhan keperawatan post pertama, kedua, dan ketiga terjadi peningkatan yang bermakna dari 77,55 sampai 105,45 tetapi belum mencapai nilai optimal.
\end{abstract}

Kata Kunci: Kepemimpinan Transaksional, Pelaksanaan Asuhan Keperawatan

\begin{abstract}
The purpose of this study was to determine the effect of head room transactional leadership on the implementation of nursing nurses' nursing care. The design of this study was Quasy Experiment with pre and post test design with control group. The results of the analysis of transactional leadership data have a significant effect on the implementation of nursing care in the intervention group with a p-value of 0,000<0.05. Whereas in the control group there were differences in the pre and post measurement values of week VI of the Implementation of Nursing Care with a p-value of 0,000<0.05. Conclusion, in the intervention group it was found that the measurement of the implementation of the first, second, and third post nursing care had a significant increase from 77.55 to 105.45 but not yet reached the optimal value.
\end{abstract}

Keywords: Transactional Leadership, Implementation of Nursing Care 


\section{PENDAHULUAN}

Rumah sakit merupakan salah satu sarana upaya kesehatan yang memberikan pelayanan kesehatan kepada masyarakat yang memiliki peran strategis dalam mempercepat peningkatan derajat kesehatan sebagai tujuan pembangunan kesehatan. Tolak ukur ukur citra sebuah rumah sakit dimata masyarakat melalui pelayanan keperawatan sehingga diperlukan profesionalisme perawat pelaksana maupun perawat pengelola dalam memberikan dan mengatur kegiatan asuhan keperawatan kepada pasien.

Rumah sakit yang merupakan sarana pelayanan kesehatan baik individu maupun masyarakat dituntut untuk menyediakan pelayanan yang terbaik bagi individu dan masyarakat tersebut. Sebagai bagian terdepan dalam memberikan pelayanan kepada individu dan masyarakat diperlukan perawat yang memberikan pelayanan keperawatan secara profesional dan akuntabel dan di belakang itu semua harus ada pemimpin yang mampu mendatangkan perubahan dari individu dan elemen organisasi untuk menjawab tantangan akan kepuasan dari pengguna layanan kesehatan tersebut. Berangkat dari tujuan mencapai kepuasan pasien maka sangatlah diperlukan kepuasan perawat itu sendiri dalam bekerjadalam melayani pasien dan memberikan kepuasan akan hasil asuhan keperawatan yang diberikan (Nursalam, 2012).

Perawat merupakan "The Caring Profession" mempunyai kedudukan penting dalam menghasilkan kualitas pelayanan kesehatan di rumah sakit, karena pelayanan yang unik dilaksanakan selama 24 jam dan berkesinambungan merupakan kelebihan tersendiri dibanding pelayanan lainnya. Oleh karena itu, rumah sakit haruslah memiliki perawat yang berkinerja baik yang akan menunjang kinerja rumah sakit sehingga dapat tercapai kepuasan pelanggan atau pasien (Arofiati \& Wahyuni, 2011).

Kinerja perawat adalah aktivitas perawat dalam mengimplementasikan sebaikbaiknya suatu wewenang, tugas dan tanggung jawabnya dalam rangka pencapaian tujuan tugas pokok profesi dan terwujudnya tujuan dan sasaran unit organisasi. Kinerja perawat sebenarnya sama dengan prestasi kerja di perusahaan. Perawat ingin diukur kinerjanya berdasarkan standar obyektifyang terbuka dan dapat dikomunikasikan. Jika perawat diperhatikan dan dihargai sampai penghargaan superior, mereka akan lebih terpacu untuk mencapai prestasi pada tingkat lebih tinggi (Faizin \& Winarsih, 2008).

Rendahnya kinerja perawat terlihat dimana ia selalu bertanya kepada dokter mengenai tindakan keperawatan padahal semestinya ia memiliki kesempatan untuk dapat merubah dan mengambil keputusan sendiri dalam hal asuhan keperawatannya sesuai kebutuhan pasien berdasarkan standar operasional pekerjaannya yang juga merupakan batasan otonomi seorang perawat yaitu standar pengkajian, standar diagnosa keperawatan, standar perencanaan, standar pelaksanaan, dan standar evaluasi (Lumbanraja \& Nizma, 2010).

Peningkatan mutu asuhan keperawatan antara lain: (1) Pemimpin yang peduli dan mendukung, (2) Sumber daya dalam pelayanan asuhan keperawatan yang dimanfaatkan secara wajar, efisiensi dan efektif, (3) Tenaga keperawatan yang mempunyai pengetahuan, sikap dan keterampilan melalui pemberian program pendidikan dan pelatihan, (4) Memenuhi standar profesi yang ditetapkan (5) Tersedianya Standar Asuhan Keperawatan (Selvia, 2012). Asuhan pasien dilakukan oleh Profesional Pemberi Asuhan (PPA) dengan banyak disiplin ilmu, memiliki peran yang jelas, kompetensi dan kewenangan, serta uraian tugas yang sesuai, sertifikasi, memiliki keterampilan individu, pengetahuan, pengalaman dalam asuhan kepada pasien (SNARS, 2018). 
Kualitas yang dimiliki oleh perawat dipengaruhi oleh tipe kepemimpinan yang tepat, Kepemimpinan merupakan unsur penting dalam menentukan kelancaran pelayanan di rumah sakit, Dengan memperhatikan karakteristik bawahan, diantaranya dengan gaya kepemimpinan transaksional (Tribowo, 2013).

Kepemimpinan adalah mengarahkan dan mempengaruhi orang lain untuk memiliki motivasi dalam mencapai suatu tujuan (Kuntoro, 2010). Kedudukan pemimpin dalam suatu organisasi sangatlah penting untuk mencapai tujuan organisasi (Subhan et al., 2012). Tanpa kepemimpinan organisasi hanya merupakan kelompok manusia yang kacau, tidak teratur dan tidak akan melahirkan perilaku bertujuan (Sudarman, 2004). Berhasil atau gagalnya suatu organisasi dalam mengemban misinya untuk mencapai tujuan, sebagian besar ditentukan oleh tipe kepemimpinan yang dijalankan oleh orangorang yang diserahi tugas-tugas kepemimpinan dalam organisasi tersebut (Subhan et al., 2012). Tipe kepemimpinan merupakan cara yang digunakan oleh seorang pemimpin untuk mencapai tujuan organisasi dengan memperhatikan unsur-unsur falsafah, ketrampilan, sifat, dan sikap karyawan.

Tipe kepemimpinan transaksional adalah kepemimpinan yang melakukan transaksi untuk memotivasi para pengikut dengan menyerukan kepentingan pribadi mereka (Yukl, 2006). Burn dalam Pawar \& Easmant (1997) mengemukakan bahwa tipe kepemimpinan tipe transaksional dapat dipilih secara tegas dan keduanya merupakan tipe kepemimpinan yang saling bertentangan.

Berdasarkan wawancara dengan 8 perawat pelaksana pada tanggal 22 November 2018 didapatkan bahwa 87,5\% kemampuan yang dimiliki belum optimal dalam pemberian asuhan keperawatan, keinginan untuk meningkatkan pengetahuan dan keterampilan sejauh ini belum mendapatkan kesempatan.

Karena manajemen rumah sakit hanya memilih perwakilan dari setiap ruangan untuk mengikuti pelatihan. Berdasarkan informasi yang disampaikan oleh perawat pelaksana $85,71 \%$ mengatakan bahwa gaya kepemimpinan kepala ruangan belum efektif, kurangnya pengawasan, bimbingan dan arahan dari kepala ruangan selama ini belum optimal, sanksi terhadap pelanggaran disiplin kurang tegas, perawat juga mengatakan pemberian punishment bagi pelanggaran disiplin kinerja lebih diperhatikan dibandingkan dengan pemberian reinforcement terhadap perawat yang melaksanakan tugas dengan baik.

\section{METODE PENELITIAN}

Desain penelitian yang digunakan pada penelitian ini adalah desain quasy eksperiment pre and post two group. Dalam penelitian ini terdapat dua kelompok group penelitian di mana yang satu sebagai kelompok kontrol dan yang satunya adalah sebagai kelompok intervensi. populasi dalam penelitian ini adalah semua Perawat pelaksana di ruang rawat inap umum sebanyak 5 ruangan di RSUD Mokoyurli Kabupaten Buol berjumlah 65 perawat, RSUD Mokopido tolitoli 4 ruangan berjumlah 73 orang.

Besar sampel yang diperlukan untuk setiap kelompok intervensi dan kelompok kontrol adalah sebesar 33 responden diambil dengan teknik purposive random sampling Penelitian ini dilakukan di RSUD Mokoyurli Kabupaten Buol sebagai kelompok intervensi dan RSUD Mokopido Toli-toli sebagai kelompok kontrol, pertimbangan pemilihan tempat penelitian ini karena Rumah Sakit ini sesuai dengan variabel judul yang akan di teliti, sehingga memungkinkan untuk memperoleh sampel sesuai dengan kriteria inklusi. 
Penelitian ini dilaksanakan dimulai dari persiapan penelitian dan proposal di ajukan pada bulan September 2018 - Februari 2019. Dan pengumpulan data di lakukan selama dua 3 bulan yaitu pada bulan maret - mei 2019 .

Dalam penelitian ini proses pengambilan dan pengumpulan data diperoleh dengan lembar Kuesioner, dan lembar observasi, SPO kepemimpinan transaksional, Modul kepemimpinan transaksional.Variable dalam penelitian ini adalah variabel independen yaitu kepemimpinan transaksional,variable dependennya adalah Pelaksanaan Asuhan Keperawatan. Pelaksanaan Asuhan Keperawatan dilakukan pengukuran selama 3 kali dalam rentang waktu yang sama juga yaitu selama 2 minggu 4 minggu dan 6 minggu

Analisa data dilakukan secara univariat, bivariat, dan multivariat dengan menggunakan metode analisis General Linear Model-Repeated Measures (GLM-RM).

\section{HASIL PENELITIAN \\ Karakteristik Responden}

Karakteristik responden berdasarkan distribusi frekuensi berdasarakan usia penelitian ini sebagian besar berusia 26-35 tahun (84,8\%) pada kelompok kasus. $(66,7 \%)$ pada kelompok kontrol. Distribusi frekuensi jenis kelamin responden dalam penelitian ini menunjukkan sebagian besar berjenis kelamin perempuan. Pada kelompok kasus $(72,7 \%)$ dan pada kelompok kontrol (84,8\%).Distribusi frekuensi responden berdasarkan pendidikan pada penelitian ini sebagian besar berpendidikan DIII Keperawatan. Pada kelompok kasus $(72,7 \%)$ dan pada kelompok kontrol $(81,8 \%)$. Pengalaman kerja perawat pelaksana dalam penelitian ini pada kelompok intervensi sebagian besar > 5 tahun $(69,7 \%)$, sedangkan pada kelompok kontrol sebagian besar mempunyai pengalaman kerja 1-5 tahun $(51,5 \%)$.

\section{Analisa Univariat}

Tabel. 1

Distribusi Responden Berdasarkan Pelaksanaan Asuhan Keperawatan Perawat Pelaksana 2019, n=66

\begin{tabular}{lcccc}
\hline \multicolumn{1}{c}{ Pengukuran } & Kelompok & Mean & SD & $\mathrm{n}$ \\
\hline Pengukuran Pre & Intervensi & 77,55 & 17,93 & 33 \\
& Kontrol & 79,12 & 15,07 & 33 \\
\cline { 1 - 3 } Pengukuran Post I Minggu ke 2 & Intervensi & 90,27 & 19,13 & 33 \\
& Kontrol & 82,39 & 13,28 & 33 \\
\cline { 1 - 3 } Pengukuran Post II Minggu ke 4 & Intervensi & 96,33 & 18,27 & 33 \\
& Kontrol & 88,15 & 17,20 & 33 \\
\cline { 1 - 3 } Pengukuran Post III Minggu ke 6 & Intervensi & 105,45 & 12,80 & 33 \\
& Kontrol & 92,67 & 17,41 & 33 \\
\hline
\end{tabular}

Berdasarkan tabel 1 distribusi rata-rata pencapaian pengukuran pada kelompok intervensi menunjukan ratarata nilai sebelum intervensi 77,55 dengan standar deviasi 17,93 sedangkan pada kelompok kontrol 79,12 dengan standar deviasi 15,07. Pada pengukuran post pertama pada kelompok intervensi setelah diberikan intervensi sebesar 90,27 dengan standar deviasi 19,13, sedangkan pada kelompok kontrol menunjukan skor rata-rata sebesar 82,39 dengan standar deviasi 13,28, pencapaian kompetensi pengukuran ke-2 pada kelompok intervensi menunjukan skor ratarata sebesar 96,33 dengan standar deviasi 18,27, sedangkan pada kelompok kontrol menunjukan skor ratarata sebesar 88,15 dengan standar deviasi 17,20, pencapaian kompetensi pengukuran ke- 
3 pada kelompok intervensi menunjukan skor rata-rata sebesar 105,45 dengan standar deviasi 12,80, sedangkan pada kelompok kontrol menunjukan skor rata-rata sebesar 92,67 dengan standar deviasi 17,41. Data ini menunjukkan pada kelompok intervensi terjadi peningkatan dari pengukuran post 1 kedua sampai dengan pengukuran ke3. kelompok kontrol pengukuran pre dan post ke 1, post ke 2 dan ke 3 terjadi peningkatan hanya nilai peningkatan lebih rendah dibandingkan dengan kelompok intervensi.

\section{Analisa Bivariat}

Tabel. 2

Perbedaan Rata-Rata Pelaksanaan Asuhan Keperawatan Sebelum dan Sesudah Diberikan Intervensi pada Kelompok Intervensi Tahun 2019, $n=66$

\begin{tabular}{lcccc}
\hline \multicolumn{1}{c}{$\begin{array}{c}\text { Variabel } \\
\text { Intervensi }\end{array}$} & Mean & N & SD & P-Value \\
\hline Pre pengukuran & 77,55 & 33 & 17,936 & 0,000 \\
Pengukuran minggu ke VI & 105,45 & 33 & 12,804 & \\
Kontrol & 79,12 & 33 & 15,074 & 0,000 \\
Pre pengukuran & 92,67 & 33 & 17,415 & \\
Pengukuran minggu ke VI & & & \\
\hline
\end{tabular}

Berdasarkan tabel 2 didapatkan bahwa rata-rata nilai pre test pelaksanaan asuhan keperawatan sebelum diberikan intervensi 77,55 dengan standar deviasi 17,936 setelah diberikan intervensi nilai rata-rata pelaksanaan asuhan keperawatan perawat pelaksana terjadi peningkatan di minggu ke 6 menjadi 105,45 dengan standar deviasi 12,804. Hasil uji statistik P-Value sebesar 0,000, disimpulkan bahwa ada perbedaan yang signifikan pelaksanaan asuhan keperawatan perawat pelaksana sebelum dan sesudah diberikan intervensi kepemimpinan transaksional.

\section{Analisa Multivariat}

Tabel. 3

Uji Levene Test Pelaksanaan Asuhan Keperawatan Kelompok Intervensi dan Kelompok Kontrol n=33 Tahun 2019

\begin{tabular}{crcc}
\hline Variabel & Levine Test & P- Value & Kesimpulan \\
\hline Pengukuran pertama & 0,049 & 0,825 & Homogen \\
Pengukuran Minggu II & 0,035 & 0,852 & Homogen \\
Pengukuran Minggu IV & 0,331 & 0,567 & Homogen \\
Pengukuran Minggu VI & 1,204 & 0,277 & Homogen \\
\hline
\end{tabular}

Berdasarkan tabel 3 di ketahui nilai signifikan untuk kelompok intervensi dan kelompok kontrol dari pengukuran awal sampai pengukuran minggu ke II, IV dan VI adalah > 0,05, dengan kata lain kedua kelompok data berasal dari populasi yang memiliki varians yang sama (homogen). 
Tabel. 4

Uji Mauchly's Pelaksanaan Asuhan Keperawatan Kelompok Intervensi dan Kelompok Kontrol n=33

\begin{tabular}{cccc}
\hline Kelompok & Mauchly & P-Value & Kesimpulan \\
\hline Intervensi & 0,564 & 0,004 & Varians tidak sama \\
Kontrol & 0,187 & 0,000 & Varians tidak sama \\
\hline
\end{tabular}

Berdasarkan tabel 4 diketahui nilai signifikan untuk kelompok intervensi dan kelompok kontrol adalah $0,000<0,05$, dengan kata lain kedua kelompok tidak memenuhi asumsi kesamaan varians.

Tabel. 5

Nilai Greenhouse-Geisser Pelaksanaan Asuhan Keperawatan Kelompok Intervensi dan Kelompok Kontrol n=33 Tahun 2019

\begin{tabular}{cccc}
\hline Kelompok & Df & F & P Value \\
\hline Intervensi & 2,287 & 27,402 & 0,000 \\
Kontrol & 1,583 & 15,398 & 0,000 \\
\hline
\end{tabular}

Berdasarkan tabel 4 ketahui nilai Greenhouse-Geisser signifikan untuk kelompok intervensi dan kelompok kontrol adalah 0,000 < 0,05, dengan kata lain Ho di tolak dan Ha di terima dengan kata lain ada pengaruh kepemimpinan transaksional terhadap Pelaksanaan Asuhan Keperawatan.

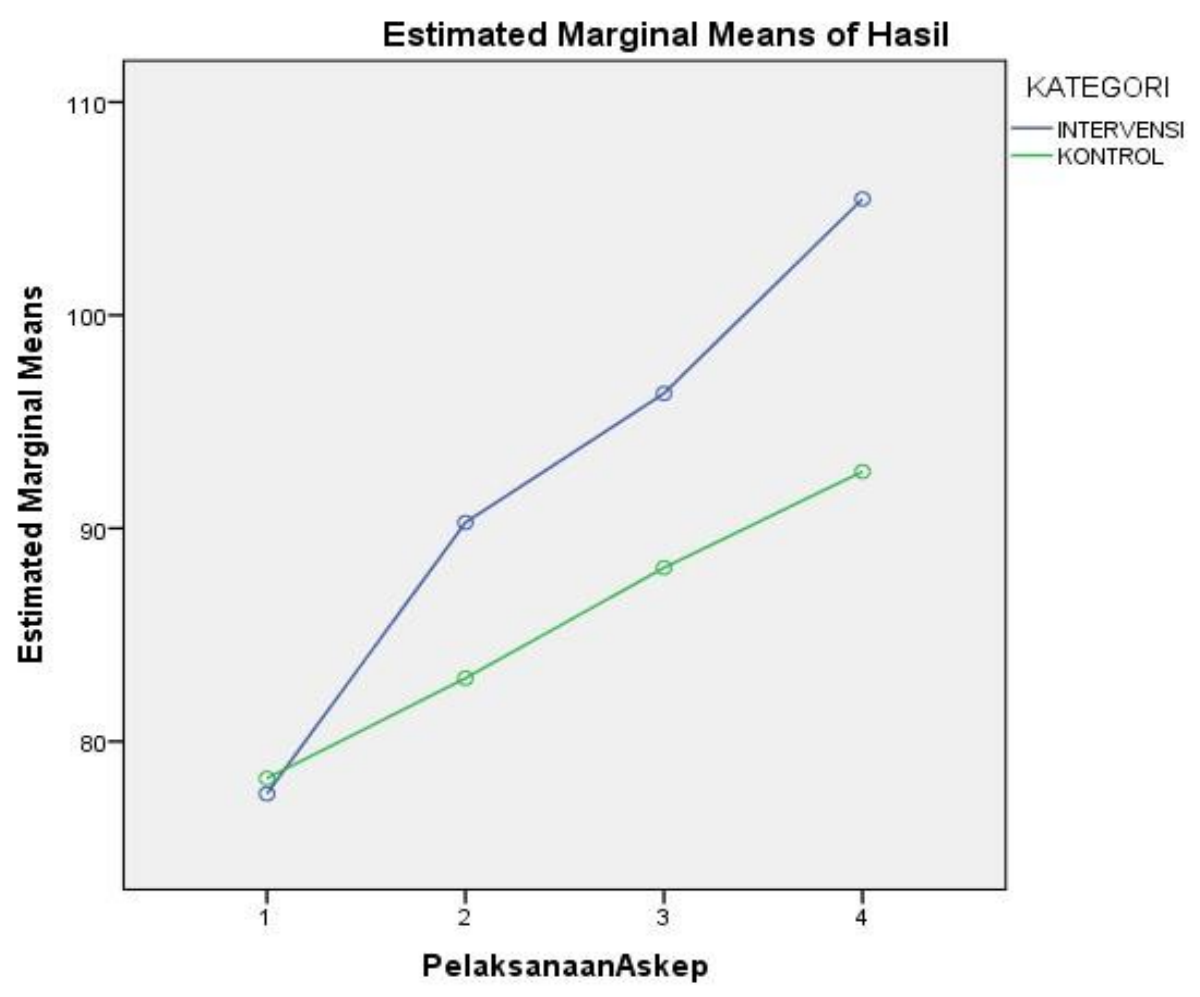

Grarik. 1

Grafik Pelaksanaan Asuhan Keperawatan Perawat Pelaksana 
Grafik peningkatan pelaksanaan asuhan keperawatan menunjukkan perubahan yang signifikan, peningkatan pelaksanaan asuhan keperawatan terjadi pada pengukuran yang ke 1,2 dan 3 pada kelompok intervensi. Akan tetapi perubahan tersebut dalam upaya meningkatkan pelaksanaan asuhan keperawatan belum mencapai titik optimal. Hal tersebut dapat dilihat dari garis grafik yang belum memperlihatkan garis datar atau stabil sampai pengukuran terakhir, sehingga dapat disimpulkan bahwa gaya kepemimpinan transaksional masih perlu ditingkatkan sebagai intervensi untuk menemukan titik optimalnya.

\section{PEMBAHASAN}

\section{Pelaksanaan Asuhan Keperawatan}

Analisa Perbedaan pelaksanaan asuhan keperawatan sebelum dan setelah diberikan intervensi kepemimpinan transaksional. Dari hasil didapatkan bahwa rata-rata pelaksanaan asuhan keperawatan sebelum diberikan intervensi 77,55, setelah diberikan intervensi kepemimpinan transaksional kepada kepala ruangan, rata-rata pelaksanaan asuhan keperawatan perawat pelaksana 105,45. Ini menunjukkan bahwa adanya pengaruh kepemimpinan transaksional kepala ruangan terhadap pelaksanaan asuhan keperawatan perawat pelaksana pada kelompok intervensi. Disisi lain penelitian Setiawan (2015) menunjukkan bahwa gaya kepemimpinan transaksional berpengaruh terhadap kinerja karyawan. Hasil penelitian ini juga menunjukkan bahwa gaya kepemimpinan transaksional memiliki pengaruh yang signifikan terhadap kinerja karyawan.

Kepemimpinan adalah mengarahkan dan mempengaruhi orang lain untuk memiliki motivasi dalam mencapai suatu tujuan (Kuntoro, 2010). Kedudukan pemimpin dalam suatu organisasi sangatlah penting untuk mencapai tujuan organisasi (Subhan et al., 2012). Tanpa kepemimpinan organisasi hanya merupakan kelompok manusia yang kacau, tidak teratur dan tidak akan melahirkan perilaku bertujuan (Sudarman, 2004). Berhasil atau gagalnya suatu organisasi dalam mengemban misinya untuk mencapai tujuan, sebagian besar ditentukan oleh tipe kepemimpinan yang dijalankan oleh orangorang yang diserahi tugas-tugas kepemimpinan dalam organisasi tersebut (Subhan et al., 2012).

Hasil penelitian ini sejalan dengan penelitian Hardianto (2011) menunjukkan bahwa, pengaruh gaya kepemimpinan transformasional dan transaksional terhadap kinerja pegawai di kantor distrik navigasi kelas II semarang dengan variabel antara kepuasan kerja mempunyai signifikansi negatif. Hasil penelitian Chiang \& Wang (2012) menunjukkan kepemimpinan transformasional berpengaruh positif terhadap kognitif dan afektif kepercayaan sedangkan pada kepemimpinan transaksional berpengaruh negatif terhadap kognitif kepercayaan. Menurut Prasetyo (2008) kepemimpinan transformasional dan transaksional berpengaruh positif pada komitmen afektif dan komitmen kontinuence. Hasil penelitian Selly (2004) menyatakan bahwa persepsi terhadap kepemimpinan transformasional dan transaksional secara bersama sama berhubungan dengan komitmen karyawan terhadap perusahaan. Oleh karena itu dapat disimpulkan bahwa kepemimpinan transformasional dan tranksasional secara bersamasama berpengaruh positif dan signifikan terhadap komitmen organisasional (Herawati \& Azzuhri, 2014). 


\section{Perbedaan Pelaksanaan Asuhan Keperawatan pada Kelompok Intervensi dan Kelompok Kontrol}

Hasil yang didapatkan bahwa pengukuran pelaksanaan asuhan keperawatan post ke 1 , post ke 2, dan post ke 3 terjadi peningkatan yang bermakna dari 77,55 sampai 105,45. Pada penelitian ini peneliti berasumsi bahwa terjadi nya peningkatan pelaksanaan asuhan keperawatan perawat pelaksana terdapat pada minggu ke 6 pada pengukuran ke 3. Dimana selama rentang waktu pengukuran perawat pelaksana di berikan bimbingan, arahan, dan pemberian penghargaan oleh kepala ruangan mengenai pelaksanaan asuhan keperawatan, penelitian ini menunjukkan bahwa semakin banyak dan sering diberikan bimbingan, pengawasan, dan penghargaan maka pelaksanaan asuhan keperawatan perawat pelaksana akan meningkat.

Menurut teori dari Patricia Banner tahapan kompeten adalah menyelesaikan pembelajaran dari situasi praktik aktual dengan mengikuti kegiatan yang lain, advance beginner akan menjadi competent. Tahap competent dari model Dreyfus ditandai dengan kemampuan mempertimbangkan dan membuat perencanaan yang diperkenalkan untuk suatu situasi dan mandiri. Konsisten, kemampuan memprediksi, dan manajemen waktu adalah penampilan pada tahap kompeten. Perawat kompeten dapat menunjukkan reponsibilitas yang lebih pada respon pasien, lebih realistik dan dapat menampilkan kemampuan kritis pada dirinya. Dengan diberikan nya kepemimpinan transaksional dengan adanya pemberian motivasi, bimbingan, pengawasan maka kemampuan pelaksanaan asuhan keperawatan yang dimiliki akan semakin meningkat, dengan adanya peningkatan kemampuan standar jenjang karir yang dimiliki oleh perawat pelaksana pun akan semakin meningkat.

Hasil yang didapatkan pada kelompok kontrol bahwa pengukuran Pelaksanaan Asuhan Keperawatan pre terjadi peningkatan 79,12 sampai dengan 92,67 pada pengukuran minggu ke 6 . Peneliti berasumsi bahwa terjadinya peningkatan karena perawat tersebut mempunyai motivasi dan cara belajar yang baik, aktif dalam bertanya kepada kepala ruangan pada setiap aktivitas dan kegiatan pemberian asuhan keperawatan, Terjadi peningkatan disebabkan perawat pelaksana yang bekerja di ruang rawat inap RS Mokopido toli-toli lebih aktif, dan ingin melakukan perubahan, sering bertanya kepada teman sejawat mengenai tugas dan tanggung jawab dalam kesehariannya. Kepala ruangan sudah menerapkan gaya kepemimpinan transaksional kepada seluruh perawat pelaksana sehingga perawat pelaksana selalu termotivasi untuk melakukan tindakan asuhan keperawatan dengan baik, komitmen dengan tindakan dan kewenangannya. Hasil Penelitian oleh Qayyum (2012) menunjukkan bahwa kepemimpinan transaksional memiliki hubungan positif, kuat dan signifikan dengan Komitmen kepada bawahannya. dengan adanya pengawasan secara rutin, bawahan akan selalu merasa di awasi, diperhatikan oleh atasan nya, sehingga bawahan akan mempertahankan kemampuan yang dimiliki.

\section{SIMPULAN}

Karakteristik dari 66 responden di RSUD Mokoyurli Kabupaten Buol dan RSUD Mokopido Kabupaten toli-toli diketahui sebagian besar berusia 26-35 tahun, jenis kelamin sebagian besar perempuan, tingkat pendidikan sebagian besar DIII keperawatan, pengalaman kerja kelompok intervensi sebagian besar > 5 tahun, sedangkan pada kelompok kontrol sebagian besar mempunyai pengalaman kerja 1-5 tahun. 
Kepemimpinan transaksional berpengaruh terhadap Pelaksanaan Asuhan Keperawatan perawat pelaksana di RSUD Mokoyurli Kabupaten Buol. Pelaksanaan Asuhan Keperawatan setelah diberikan intervensi kepemimpinan transaksional terjadi peningkatan signifikan pada pengukuran post 1 , post 2 , dan post ke 3 , namun belum mencapai nilai maksimum dari Pelaksanaan Asuhan Keperawatan.

\section{SARAN}

Kepemimpinan transaksional meningkatkan pelaksanaan asuhan keperawatan perawat pelaksana di RSUD Mokoyurli Kabupaten Buol. Sehingga dapat dijadikan pertimbangan dalam penerapan gaya kepemimpinan transaksional oleh kepala ruangan khususnya di ruang rawat inap RSUD Mokoyurli Kabupaten Buol.

\section{DAFTAR PUSTAKA}

Arofiati, F., \& Wahyuni, W. (2011). Hubungan antara Tingkat Pengetahuan Perawat tentang Kode Etik Keperawatan dan Hukum Kesehatan dengan Kinerja Perawat dalam Memberikan Asuhan Keperawatan di RS. PKU Muhammadiyah Yogyakarta Tahun 2009. Jurnal Kesehatan Suara Forikes, 11(2), 117

Chiang, C. F., \& Wang, Y. Y. (2012). The Effects of Transactional and Transformational Leadership on Organizational Commitment in Hotels: The Mediating Effect of Trust'. Journal Hotel Bus Manage, 1

Faizin, A., \& Winarsih, W. (2008). Hubungan Tingkat Pendidikan dan Lama Kerja Perawat dengan Kinerja Perawat di RSU Pandan Arang Kabupaten Boyolali. Jurnal Berita Ilmu Keperawatan, 1(3), 138

Hardianto, E. (2011). Pengaruh Kepemimpinan terhadap OCB, Kepuasan Kerja dan Komitmen Organisasi pada Tenaga Perawat di PKU Muhammadiyah Yogyakarta

Herawati, H., \& Azzuhri, M. (2014). Pengaruh Tipe Kepemimpinan Transformasional dan Transaksional Kepala Ruangan terhadap Komitmen Organisasional Perawat di RSI Unisma Malang. Jurnal Aplikasi Manajemen, 12(4), 621-630

Kuntoro, K. (2010). Manajemen Keperawatan. Yogyakarta: Mulia Medika

Lumbanraja, P., \& Nizma, C. (2010). Pengaruh Pelatihan dan Karakteristik Pekerjaan terhadap Prestasi Kerja Perawat di Badan Pelayanan Kesehatan Rumah Sakit Umum Daerah Langsa. Jurnal Manajemen dan Kewirausahaan, 12(2), 143

Nursalam, N. (2012). Manajemen Keperawatan. Edisi 3. Jakarta: Salemba Medika

Pawar, B. S., \& Easmant, K. K. (1997). The Nature and Implication of Contextual Influence on Transaksional Leadership; A conceptual Examination Academy of Managemen Review

Prasetyo, A. J. H. (2008). Keterkaitan antara Kepemimpinan Transformasional dan Transaksional dengan Komitmen Organisasional di PT Kereta Api Indonesia Stasiun Solo Balapan Surakarta

Qayyum, A. (2012). Impact of Transactional and Laissez Faire Leadership Style on Motivation in Lahore Pakistan. International Journal of Business and Social Science, 3(7)

Selly, Y. B. (2004). Komitmen Karyawan pada Perusahaan Ditinjau dari Kepemimpinan Transformational dan Transaksional. Jurnal Psikologi, 2(2)

Selvia, H. (2012). Buku Standar Asuhan Keperawatan (SAK). Surabaya

Setiawan, E. Y. (2015). Pengaruh Gaya Kepemimpinan Transformasional dan Transaksional terhadap Kinerja Karyawan PT. Iss Indonesia di Rumah Sakit National Surabaya. Jurnal Manajemen Magistra, 1(1) 
Standar Nasional Akreditasi Rumah Sakit. (2018). Edisi 1

Subhan, Z., Musnadi, S., \& Sabri, M. (2012). Pengaruh Kepemimpinan, Motivasi dan Budaya Organisasi terhadap Kinerja Pegawai Administrasi IAIN Ar Raniry Banda Aceh. Manajemen Pasca Sarjana Syiah Kuala, 2(1), 86

Sudarman, D. (2004). Motivasi Kepemimpinan dan Efektifitas Kelompok. Jakarta: Asdi Mahasatya

Tribowo, C. (2013). Manajemen Pelayanan Keperawatan di Rumah Sakit. Jakarta. CV: Trans Info Media TIM

Yukl, G. (2006). Leadership in Organization. New Jersey: Pearson Education 